\title{
Hubungan tingkat pengetahuan ibu tentang kesehatan gigi anak dengan tingkat keparahan karies anak TK di Kota Tahuna
}

\author{
${ }^{1}$ Christian Rompis, \\ ${ }^{2}$ Damajanty Pangemanan \\ ${ }^{3}$ Paulina Gunawan
}

\author{
${ }^{1}$ Kandidat Skripsi Program Studi Pendidikan Dokter Gigi Fakultas Kedokteran \\ ${ }^{2}$ Bagian Fisiologi Fakultas Kedokteran \\ ${ }^{3}$ Program Studi Pendidikan Dokter Gigi Fakultas Kedokteran \\ Universitas Sam Ratulangi Manado \\ E-mail: ChrisRompis@yahoo.co.id
}

\begin{abstract}
Mother's knowledge about children dental health is very important. It could be observed from some aspects such as knowledge of the causes of dental health problems, children dental care, dietary, and time schedule to the dentist. Def-t index is a measurement of the severity of dental caries in children. This study aimed to determine the relationship of mother's knowledge about the dental health and dental caries severity of kindergarten children in the town of Tahuna. This was an analytical study with a cross-sectional design. There were 65 kindergarten children as samples. Data were collected by using a questionnaire and the def-t examination sheet. The results showed as follows: the mother's knowledge about the dental health of children of good category $93.8 \%$ and poor category $6.1 \%$. The examination of the severity of dental caries resulted in $4.61 \%$ low severity category, $26.1 \%$ moderate severity category, $60 \%$ high severity category, and very high severity category $9.23 \%$. The contingency coefficient correlation test showed a significance of $0.270(>p=0.05)$; therefore, the relationship was weak. Conclusion: There was no relationship between mother's knowledge about dental health of the children and caries severity of kindergarten children in the city of Tahuna.
\end{abstract}

Keywords: def- t, severity of caries, knowledge of mother

\begin{abstract}
Abstrak: Pengetahuan ibu tentang kesehatan gigi anak menjadi salah satu hal yang penting di era sekarang ini. Pengetahuan ibu mengenai kesehatan gigi anak dapat dilihat dari beberapa aspek yaitu pengetahuan tentang penyebab masalah kesehatan gigi, akibat masalah kesehatan gigi, perawatan gigi anak, pengaturan makanan serta waktu memeriksakan gigi anak ke dokter gigi. Tingkat keparahan karies merupakan pengukuran seberapa parah karies gigi pada anak dengan menggunakan indeks def-t. Penelitian ini bertujuan untuk mengetahui hubungan pengetahuan ibu tentang kesehatan gigi terhadap tingkat keparahan karies anak TK di kota Tahuna. Jenis penelitan ini analitik dengan rancangan potong lintang. Jumlah sampel yang diambil dari beberapa TK di Kota Tahuna sebanyak 65 anak. Teknik pengumpulan data mengunakan kuesioner dan lembar pemeriksaan def-t. Hasil penelitian menunjukkan pengetahuan ibu tentang kesehatan gigi anak di Kota Tahuna kategori baik 93,8\% sedangkan kategori buruk 6,1 \%. Pemeriksaan tingkat keparahan karies gigi mendapatkan kategori keparahan rendah 4,61\%, kategori keparahan sedang 26,1\%, kategori keparahan tinggi 60\%, dan kategori keparahan sangat tinggi 9,23\%. Hasil analisis menggunakan uji korelasi koefisien kontingensi mendapatkan hasil signifikansi $0,270(>p=0,05)$, yang menunjukkan hubungan yang terjadi lemah. Simpulan: Tidak terdapat hubungan antara pengetahuan ibu tentang kesehatan gigi anak dengan tingkat keparahan karies anak TK di Kota Tahuna.
\end{abstract}

Kata kunci : def- t, tingkat keparahan karies, pengetahuan ibu 
Pengetahuan adalah hasil ranah tahu dan ini terjadi karena seseorang melakukan penginderaan terhadap objek tertentu, melalui panca indera manusia. ${ }^{1}$ Pengetahuan mengenai kesehatan gigi anak menjadi hal keharusan bagi seorang ibu demi perkembangan dan pertumbuhan gigi - geligi anak yang baik. Pengetahuan dan kemampuan orang tua dalam menjaga kesehatan gigi anak dapat dipengaruhi oleh beberapa hal, antara lain yaitu usia, pendidikan, status sosial ekonomi, pengalaman, informasi media massa dan lingkungan. ${ }^{2}$

Pengetahuan ibu yang merupakan orang terdekat dengan anak dalam pemeliharaan kesehatan memberikan pengaruh yang signifikan terhadap sikap dan perilaku anak. ${ }^{3}$ Anak-anak usia taman kanak-kanak umumnya tidak tahu dan belum mampu untuk menjaga kesehatan rongga mulut mereka, sehingga orang tualah bertanggung jawab untuk mendidik mereka dengan benar.

Kesehatan gigi anak menjadi perhatian khusus di era modern sekarang ini. Permasalahan karies gigi pada anak usia sekolah dasar menjadi penting karena karies gigi menjadi indikator keberhasilan upaya pemeliharaan kesehatan gigi anak .

Angka prevalensi nasional tahun 2013 masalah kesehatan gigi dan mulut mencapai presentase sebesar 25,9\% dan sebanyak 14 provinsi prevalensinya melebihi angka nasional tersebut. Sulawesi Utara pada tahun 2013 memiliki angka presentase penduduk yang bermasalah gigi dan mulut sebanyak 31,6\%, yang menerima perawatan dari tenaga medis gigi jauh lebih rendah yaitu 25\%. Hal lain yang menjadi perhatian yaitu proporsi penduduk bermasalah gigi dan mulut pada kelompok umur anak sekolah TK yaitu usia 1-4 tahun sebesar 10,4\% dan anak usia 5-9 tahun sebesar 28,9\%. ${ }^{4}$ Penelitian yang dilakukan oleh Susi tahun 2011 di beberapa taman kanak-kanak di Padang menunjukan anak yang memiliki ibu yang berpendidikan sarjana memiliki status karies baik sebesar 53,3\%, dan anak yang memiliki ibu yang tidak sarjana, mempunyai status karies buruk lebih tinggi yaitu 58,3\%. ${ }^{5}$ Hal yang sama pada penelitian yang dilakukan oleh Solikin tahun 2013 di Karanganyar, menunjukan bahwa, pengetahuan ibu dengan kategori kurang baik anaknya mengalami karies gigi sebesar 97,6\% sedangkan tingkat pengetahuan ibu dengan kategori baik anaknya yang mengalami karies sebanyak $12,5 \%{ }^{6}$

Umumnya anak-anak yang baru memasuki usia sekolah mempunyai resiko karies yang tinggi, karena pada usia sekolah ini anak-anak biasanya suka jajan makanan dan minuman sesuai keinginannya. ${ }^{7}$ Penyakit karies pada anak banyak dan sering terjadi namun kurang mendapat perhatian dari orang tua dengan anggapan bahwa gigi anak akan digantikan gigi tetap. ${ }^{8}$ Banyak kejadian karies sekarang ini disebabkan kurangnya pengetahuan orang tua tentang pemilihan jenis makanan dan perawatan gigi yang benar bagi anakanaknya terutama anak usia sekolah. ${ }^{9}$ Pola asuh orangtua khususnya ibu berperan penting dalam merubah kebiasaan yang buruk bagi kesehatan anak. Sikap,perilaku dan kebiasaan orangtua selalu dilihat, dinilai, dan ditiru oleh anaknya yang kemudian semua itu secara sadar atau tidak sadar akan diresapi dan menjadi kebiasaan pula bagi anak-anaknya. ${ }^{10}$

Penelitian ini bertujuan untuk mengetahui hubungan tingkat pengetahuan ibu tentang kesehatan gigi terhadap tingkat keparahan karies di beberapa taman kanakkanak yang ada di kota Tahuna

\section{BAHAN DAN METODE PENELITIAN}

Desain penelitian ini bersifat analitik dengan rancangan potong lintang. Penelitian dilaksanakan di beberapa TK yang ada di kota Tahuna pada bulan September - Oktober 2015.

Populasi penelitian ini yaitu siswa TK yang berjumlah 87 anak. Besar sampel yang digunakan ialah sampel eksperimen sederhana sebanyak 65 responden. Teknik yang dipakai yaitu total sampling sesuai dengan yang memenuhi kriteria inklusi yaitu siswa dan ibu yang bersedia untuk diteliti, hadir pada saat penelitian, dan 
siswa berusia 4-6 tahun. Variabel penelitian ini ialah pengetahuan ibu tentang kesehatan gigi anak dan tingkat keparahan karies.

Pengukuran dan penilaian karies pada responden anak yang diteliti dengan menggunakan indeks def-t. Gigi yang tidak dihitung pada indeks def yaitu gigi yang hilang termasuk gigi anerupsi dan gigi yang hilang secara kongenital, gigi supernumerari, dan gigi yang direstorasi untuk alasan lain selain karies gigi.

Rumus penghitungan def yaitu :

Jumlah d (Decay) + e (indices for extraction $)+\mathrm{f}$ (filling). Untuk menghitung rata-rata dari def di gunakan rumus:

Jumlah $\mathrm{d}+\mathrm{e}+\mathrm{f}$

Jumlah anak yang di periksa

Pengetahuan ibu terhadap pertanyaan yang diberikan dalam kuesioner, seperti pertanyaan mengenai penyebab masalah kesehatan gigi pada anak. Kuesioner yang diberikan berisi tentang pengertian kesehatan gigi, penyebab masalah kesehatan gigi, akibat masalah kesehatan gigi, masalah kesehatan gigi, dan perawatan gigi. Pada pengisian kuesioner ibu yang menjawab $>11$ pertanyaan dengan benar dikategorikan pengetahuan baik, dan ibu yang menjawab <11 pertanyaan kuesioner dikategorikan pengetahuan buruk.

Alat yang digunakan ialah sarung tangan, autoclave, masker, diagnostic set (kaca mulut dan sonde), informed consent, lembar pemeriksaan def-t, lembar kuesioner pengetahuan ibu tentang kesehatan gigi anak.

Sebelum dilakukan penelitian diberikan penjelasan tentang penelitian yang dilakukan, kemudian diberikan lembaran informed consent kepada ibu dari siswa untuk ditandatangani, diteruskan dengan pengisian kuesioner tersebut. Dilanjutkan dengan pemeriksaan tingkat keparahan karies gigi pada siswa mengunakan diagnostic set.

Data diolah dan dianalisis menggunakan uji korelasi koefisien kontingensi dan disajikan dalam bentuk tabel distribusi frekuensi.

\section{HASIL PENELITIAN}

Penelitian ini dilakukan pada bulan Oktober 2015 pada anak taman kanakkanak di beberapa TK yang ada di kota Tahuna yaitu TK Kartika Kodim 1301 Satal, TK GMIST Eklesia Tahuna, dan TK Katolik St. Agustinus Tahuna. Populasi berjumlah 87 orang anak, namun yang memenuhi kriteria inklusi dan eksklusi sebanyak 65 orang anak.

Distribusi mengenai pengetahuan ibu tentang kesehatan gigi anak didapatkan dari penghitungan mengunakan kuesioner kemudian disajikan dalam bentuk skor angka dan kemudian skor tersebut dapat menunjukan kategori pengetahuan ibu. Pengisian kuesioner pengetahuan ibu tentang kesehatan gigi anak di TK Kartika Kodim 1301 Satal di dapatkan sampel sebanyak 13 orang ibu, TK GMIST Eklesia Tahuna 9 orang ibu, dan TK Katolik Santo Agustinus Tahuna sebanyak 43 orang ibu.

Pada Tabel 1 dapat dilihat bahwa pengisian kuesioner pengetahuan ibu menunjukkan pengetahuan ibu di TK Kartika Kodim 1301 Satal 100\% memiliki pengetahuan baik; di TK GMIST Eklesia Tahuna ibu dengan kategori pengetahuan baik berjumlah 8 orang $(88,8 \%)$ dan ibu berpengetahuan buruk 1 orang (11,1\%); dan di TK Katolik Santo Agustinus Tahuna ibu dengan kategori pengetahuan baik berjumlah 40 orang $(93,1 \%)$ dan ibu dengan kategori pengetahuan buruk berjumlah 3 orang $(6,97 \%)$.

\section{Hasil pemeriksaan tingkat keparahan karies gigi anak di beberapa TK di Kota Tahuna}

Pemeriksaan tingkat keparahan karies gigi mendapatkan tingkat keparahan karies gigi di TK Kartika Kodim 1301 Satal sebanyak 13 orang anak, TK GMIST Eklesia Tahuna 9 orang anak, dan TK Katolik Santo Agustinus Tahuna 43 orang anak. Hasil pemeriksaan mengenai tingkat keparahan karies pada anak dapat dilihat pada Tabel 2. 
Rompis, Pangamanan, Gunawan: Hubungan tingkat pengetahuan ibu ...

Tabel 1. Distribusi pengisian kuesioner pengetahuan ibu tentang kesehatan gigi anak di beberapa TK di Kota Tahuna

\begin{tabular}{ccccccc} 
& \multicolumn{2}{c}{ TK Kartika Kodim 1301 Satal } & \multicolumn{2}{c}{ TK GMIST Eklesia Tahuna } & TK Katolik Santo Agustinus Tahuna \\
\cline { 2 - 7 } Kategori Pengetahuan Ibu & $\mathrm{n}$ & $\%$ & $\mathrm{n}$ & $\%$ & $\mathrm{n}$ & $\%$ \\
\hline Pengetahuan Baik & 13 & 100 & 8 & 88,8 & 40 & 93,3 \\
\hline Pengetahuan Buruk & 0 & 0 & 1 & 11,2 & 3 & 6,97 \\
\hline \multicolumn{1}{c}{ Jumlah } & 13 & 100 & 9 & 100 & 43 & 100 \\
\hline
\end{tabular}

Tabel 2. Distribusi Tingkat Keparahan Karies Gigi Anak di beberapa TK yang ada di kota Tahuna

\begin{tabular}{|c|c|c|c|c|c|c|c|}
\hline \multirow{2}{*}{ Kategori Karies } & \multicolumn{2}{|c|}{ TK Kartika Kodim 1301 Satal } & \multicolumn{2}{|c|}{ TK GMIST Eklesia Tahuna } & \multicolumn{2}{|c|}{ TK Katolik Santo Agustinus Tahuna } & \multirow{2}{*}{ Total } \\
\hline & $\mathrm{n}$ & $\%$ & $n$ & $\%$ & $\mathrm{n}$ & $\%$ & \\
\hline Sangat Rendah & 0 & 0 & 0 & 0 & 0 & 0 & 0 \\
\hline Rendah & 0 & 0 & 0 & 0 & 0 & 0 & 0 \\
\hline Sedang & 0 & 0 & 3 & 3,33 & 17 & 39,5 & 20 \\
\hline Tinggi & 13 & 100 & 0 & 0 & 26 & 61,4 & 39 \\
\hline Sangat Tinggi & 0 & 0 & 6 & 6,67 & 0 & 0 & 6 \\
\hline Jumlah & 13 & 100 & 9 & 100 & 43 & 100 & 65 \\
\hline
\end{tabular}

Tabel 2 menunjukkan distribusi hasil pemeriksaan tingkat keparahan karies gigi pada beberapa siswa di kota Tahuna. Kategori tingkat keparahan karies rendah 4,61\% (3 anak), kategori tingkat keparahan karies sedang 26,1\% (17 anak), kategori tingkat keparahan karies tinggi 60\% (39 anak), dan kategori tingkat keparahan karies sangat tinggi 9,23\% (6 anak). Uji korelasi koefisien kontingensi dilakukan untuk mengetahui adanya hubungan antara pengetahuan ibu tentang kesehatan gigi anak dengan tingkat keparahan karies gigi (Tabel 3).

Tabel 3. Hasil Uji Korelasi Koefisien Kontingensi

\begin{tabular}{|lc|r|r|}
\hline & \multicolumn{1}{c|}{ Symmetric Measures } \\
\hline Nominal by Nominal & Contingency Coefficient & \multicolumn{1}{c|}{ Value } & Approx. Sig. \\
N of Valid Cases & & 67 & .270 \\
\hline
\end{tabular}

Dari analisis di atas (Symmetric Measures) didapatkan koefisien kontigensi (Contingency Coefficient) sebesar 0,270. Karena nilai lebih mendekati 0, maka hubungan yang terjadi lemah.

Untuk mengetahui hubungan berarti atau tidak, maka dilakukan pengujian signifikansi. Dari hasil output diatas diketahui bahwa signifikansi (Approx Sig) adalah 0,270 lebih dari $\mathrm{p}=0,05$ maka hipotesis 0 diterima, artinya tidak ada hubungan antara pengetahuan ibu dengan tingkat keparahan karies gigi. Selain itu dapat dilihat pula persentase pengetahuan ibu terhadap tingkat keparahan karies gigi anak (Tabel 4)

Tabel 4. Tabel Silang Pengetahuan Ibu dengan Tingkat Keparahan Karies Gigi Anak

\begin{tabular}{|c|c|c|c|c|c|}
\hline \multirow{3}{*}{$"$} & \multirow{3}{*}{ mi Karies } & \multicolumn{4}{|c|}{ Kategori Pengetahuan Ibu } \\
\hline & & \multicolumn{2}{|c|}{ Pengetahuan Ibu Baik } & \multicolumn{2}{|c|}{ Pengetahuan Ibu Buruk } \\
\hline & & $\mathrm{n}$ & $\%$ & $\mathrm{n}$ & $\%$ \\
\hline & 1 & 0 & 0 & 0 & 0 \\
\hline \multicolumn{2}{|l|}{ Rendah } & 0 & 0 & 0 & 0 \\
\hline \multicolumn{2}{|l|}{ Sedang } & 20 & 32,7 & 0 & 0 \\
\hline \multicolumn{2}{|l|}{ Tinggi } & 36 & 59,2 & 3 & 75 \\
\hline \multicolumn{2}{|c|}{ Sangat Tingoi } & 5 & 8,29 & 1 & 25 \\
\hline & Jumlah & 61 & 100 & 4 & 100 \\
\hline
\end{tabular}




\section{BAHASAN}

\section{Pengetahuan ibu tentang kesehatan gigi anak}

Pengetahuan ibu tentang kesehatan gigi sangat penting karena merupakan faktor yang penting dalam memberikan pengaruh pada kesehatan dan penyakit gigi anak. $^{11}$ Penelitian yang dilakukan di Sangihe mengenai pengetahuan ibu mencakup dua kategori pengetahuan yaitu pengetahuan baik dan pengetahuan buruk.

Pengetahuan ibu didasari juga oleh beberapa faktor seperti: pekerjaan, tingkat pendidikan, pengalaman mengasuh anak, lingkungan tempat tinggal serta status ekonomi. Salah satu faktor yang jelas mempengaruhi yaitu lingkungan tempat tinggal responden. Lingkungan tempat tinggal responden termasuk dekat dengan kota yaitu Kota Tahuna. Kedekatan dengan perkotaan menyebabkan kesempatan responden untuk memperoleh informasi tentang kesehatan gigi anak dari media massa, penyuluhan, atau informasi dari tenaga kesehatan relatif mudah .

Informasi mengenai kesehatan gigi yang disampaikan oleh iklan pasta gigi atau sikat gigi, maupun iklan layanan masyarakat tentang pemeliharaan gigi merupakan salah satu sumber informasi tentang kesehatan gigi anak yang diterima ibu. Informasi yang diterima tersebut secara tidak sadar dapat meningkatkan pengetahuan ibu tentang kesehatan gigi anak. Penelitian yang dilakukan oleh Sumerti di Distrik Kuta Badung menunjukan bahwa pengetahuan ibu juga sangat berpengaruh pada karies yang dialami oleh anak, karena pengetahuan ibu itu juga berfungsi dalam praktik pencegahan dini karies. ${ }^{12}$

Penelitian yang dilakukan di Tahuna menunjukan bahwa rata-rata pengetahuan ibu yang baik mengenai hal-hal yang di tanyakan dalam kuesioner akan tetapi tidak mempunyai pengaruh berarti dalam mencegah karies gigi anak dalam tabel 3 diuraikan bahwa TK GMIST Eklesia Tahuna mempunyai kriteria tingkat keparahan karies yang sangat tinggi di bandingkan dua TK lainnya yang ada di
Kota Tahuna Dalam analisa secara statistik didapatkan hasil bahwa, tidak ada hubungan antara pengetahuan ibu dengan tingkat keparahan karies.

\section{Tingkat Keparahan Karies Gigi Anak}

Tingkat keparahan karies pada anak taman kanak kanak di kota Tahuna pada kategori rendah sebanyak 4,61\% (3 anak), kategori sedang sebanyak 35,3\% (23 anak), kategori tinggi 60\% (39 anak), dan kategori sangat tinggi 9,23\% (6 anak).

Karies seringkali belum di jadikan prioritas oleh orang tua dalam menjaga kesehatan gigi anak, salah satu studi yang dilakukan oleh Puspitoningsih ${ }^{13}$ di TK Dharma Wanita Kecamatan Kemusu Boyolali menunjukan sebanyak 64\% ibu yang menyatakan anaknya mengalami karies gigi. Para ibu menggangap karies bukan masalah yang serius bagi kesehatan gigi anak, ibu tidak pernah memeriksakan kesehatan gigi anak ke puskesmas atau dokter gigi dan anak tidak di ajarkan untuk mengosok gigi 2 kali sehari.

Karies gigi pada anak TK dikota Tahuna masih begitu tinggi disebabkan masih begitu banyak faktor-faktor penyebab karies yang belum menjadi perhatian orang tua. Status gizi berkaitan dengan makanan yang dikonsumsi oleh anak- anak baik itu di rumah maupun di lingkungan sekolah menjadi perhatian penting. Anak-anak di Sangihe di beberapa tempat masih mengonsumsi beberapa snack tradisional Sangihe yang tergolong snack keras dan dapat merusak gigi. Hal inilah yang menjadi salah satu perhatian mengapa di Sangihe tingkat keparahan karies masih cukup tinggi.

\section{Hubungan pengetahuan ibu tentang kesehatan gigi anak dengan tingkat keparahan karies anak TK di Kota Tahuna}

Untuk mengetahui hubungan berarti atau tidak, maka dilakukan pengujian signifikansi. Dari hasil uji diketahui bahwa signifikansi (Approx Sig) adalah 0,270 dimana nilai $p$ lebih besar dari 0,05 maka hipotesis 0 di terima, artinya tidak ada 
hubungan antara pengetahuan ibu dengan tingkat keparahan karies gigi.

Dalam analisis secara statistik didapatkan hasil bahwa, tidak ada hubungan antara pengetahuan ibu dengan tingkat keparahan karies, hal itu juga sesuai dengan penelitian yang dilakukan oleh Bahuguna di India ${ }^{14}$ yang menyatakan bahwa selain pengetahuan, yang berpengaruh terhadap kesehatan gigi anak yaitu sikap dan kesadaran orangtua. Inisiatif orang tua merupakan hal penting dalam upaya kesehatan gigi anak. Inisiatif orang tua dalam hal ini berperan penting guna upaya pencegahan penyakit gigi pada anak juga sebagai promotif terhadap masalah kesehatan gigi yang ada. Menurut Worang ${ }^{15}$ dalam penelitian yang dilakukan pada anak prasekolah di Manado, pendidikan dan pengetahuan orang tua tidak menjamin perilaku sehari - hari anak untuk merawat kesehatan gigi dan mulu mereka. Peran serta dan perhatian dari orang tualah yang sangat dibutuhkan oleh anak usia prasekolah.

Masa anak merupakan dasar pembentukan fisik dan kepribadian pada masa berikutnya. Dengan kata lain, masa anak-anak merupakan masa emas mempersiapkan seorang individu menghadapi tuntutan zaman sesuai potensinya. ${ }^{16}$ Jadi setiap anak berhak mendapatkan perhatian dari orang tua khususnya kesehatan gigi agar turut meningkatkan potensi anak di masa pertumbuhan dan perkembangannya

Sangihe, merupakan salah satu kabupaten kepulauan di Sulawesi Utara yang masyarakatnya masih terbatas sarana dan prasarana kesehatannya. Masalah akses ke sarana pelayanan kesehatan serta kurangnya tenaga kesehatan, menjadi salah satu masalah yang belum bisa teratasi sampai saat sekarang ini. Letak geografis daerah yang terdiri dari banyak pulau yang merupakan tapal batas paling utara dari NKRI juga sering menghambat tercapainya pelayanan kesehatan secara utuh dan menyeluruh. Bagi sebagian besar masyarakat kepulauan, masalah kesehatan gigi khususnya kesehatan gigi anak belum menjadi prioritas utama disebabkan kurangnya sosialisasi, media juga pemahaman tentang betapa pentingnya menjaga kesehatan gigi anak yang sangat berpengaruh pada masa pertumbuhan dan perkembangan anak

\section{SIMPULAN}

Dari hasil penelitian dan bahasan dapat disimpulkan bahwa tidak terdapat hubungan antara pengetahuan ibu tentang kesehatan gigi anak dengan tingkat keparahan karies anak TK di Kota Tahuna.

\section{SARAN}

1. Meningkatkan kerjasama antara orang tua, tenaga pendidik dan dokter dalam menjaga kesehatan gigi anak baik itu di lingkungan sekolah dan di lingkungan keluarga.

2. Mengadakan pemeriksaan gigi rutin serta kegiatan sikat gigi massal dan penyuluhan kepada orang tua tentang betapa pentingnya menjaga kesehatan gigi massal.

3. Bekerjasama dengan instansi terkait di daerah untuk melakukan pengambilan data mengenai kesehatan gigi khususnya kesehatan gigi anak guna melengkapi data-data mengenai kesehatan gigi di Kabupaten Kepulauan Sangihe.

\section{DAFTAR PUSTAKA}

1. Notoadmodjo S. Promosi Kesehatan dan Ilmu Perilaku. Jakarta: Penerbit Rinneka Cipta, 2007; p. 77-82.

2. Haeriyah. Tingkat kepedulian orangtua terhadap pemeliharaan kesehatan gigi dan mulut anak usia 6-36 bulan di Kelurahan Tamalanrea Makasar. [Skripsi]. Makassar: Fakultas Kedokteran Gigi Universsitas Hasanudin, 2013.

3. Natamiharja J, Dwi NS. Hubungan pendidikan, pengetahuan, dan perilaku ibu terhadap status karies gigi balitanya. Dentika Dental Journal. 2010;15(1):37-41.

4. Badan Penelitian dan Pengembangan Kesehatan. Riset Kesehatan Dasar. Departemen Kesehatan Republik 
Indonesia, 2013.

5. Susi, Bachtiar H, Azmi U. Hubungan status sosial ekonomi orang tua dengan karies gigi sulung pada anak umur 4 dan 5 tahun. Majalah Kedokteran Andalas. 2012;1(36):96-104.

6. Solikin, Muhlisin HM, Kartinah A. Hubungan tingkat pengetahuan orang tua tentang kesehatan gigi dan mulut dengan kejadian karies gigi pada anak prasekolah di TK 01 Pertiwi Karangbangun Karanganyar. Surakarta: Program Studi Ilmu Keperawatan Fakultas Ilmu Kesehatan Universitas Muhammadiyah; 2013.

7. Worotitjan I, Mintjelungan $\mathrm{CN}$, Gunawan P. Pengalaman karies gigi serta pola makan dan minum pada anak sekolah dasar di desa Kiawa kecamatan Kawangkoan Utara, Jurnal e-Gigi (eG). 2013;1(1):59-68.

8. Sari SA. Hubungan kebiasaan mengosok gigi dengan timbulnya karies gigi pada anak usia sekolah kelas 4-6 di SDN Ciputat 6 Tangerang Selatan Provinsi Banten tahun 2013 [Skripsi]. Jakarta: Program Studi Ilmu Keperawatan Fakultas Kedokteran dan Ilmu Kesehatan, Universitas Islam Negeri Syarif Hidayatullah; 2014.

9. Bidjuni M, D’Arc AJ, Mokoagow J. Pola asuh orangtua dan karies gigi pada siswa kelas 5 dan 6 SD Kristen 10 Kotamobagu. JIK.2014;8(2).
10.Aisyah S. Pengaruh pola asuh orangtua terhadap tingkat agresivitas anak. Jurnal MEDTEK. 2010;2(1).

11.Jayanti CD. Hubungan tingkat pengetahuan ibu tentang karies gigi dengan kejadian karies gigi pada anak TK Aisyiyah Kateguhanan Sawit Boyolali. Surakarta: Fakultas Ilmu Kesehatan Universitas Muhamadiyyah, 2012.

12.Sumerti NN. Faktor-faktor yang berhubungan dengan perilaku ibu dalam deteksi dini karies gigi pada anak balita di Kecamatan Kuta Utara Kabupaten Badung. Jurnal Kesehatan Gigi. 2013;1(1):6.

13.Puspitoningsih N, Safitri W, Istiningtyas A. Persepsi ibu tentang karies gigi TK Dharma Wanita Kecamatan Kemusu Boyolali. Surakarta: Program Studi Keperawatan Stikes Kusuma Husada; 2012.

14.Bahuguna R, Jain A, Khan SA. Knowledges and attitudes of parents regarding child dental care in Indian Population. Asian Journal of Oral Health and Allied Sciences. 2011;1(1):9-12.

15.Worang TY, Pangemanan DHC, Wicaksono DA. Hubungan tingkat pengetahuan orang tua dengan kebersihan gigi dan mulut anak di TK Tunas Bhakti Manado. e-Gigi. 2014;2(2).

16.Fadhli, Aulia. Buku Pintar Kesehatan Anak. Yogjakarta: Pustaka Anggrek, 2010; p. 10. Available from: google.books.co.id. 